\title{
THE RISKS ATTENDING THE USE OF CARBURETTED WATER-GAS FOR DOMESTIC LIGHTING PURPOSES.*
}

\author{
By Jонx HALDANE, M.D., F.R.S., \\ Lecturer in Physiology, University of Oxford.
}

Durisa the last few years, what is technically known as carburetted water-gas has been very generally introduced in the United States instead of ordinary coal-gas for domestic lighting and heating purposes. A partial change in the same direction has been and is being carried out in many towns in this country, $t$ and has given rise to a good deal of uneasiness, on account of the real or supposed risks of poisoning by water-gas. The subject is therefore one of some interest from a public health point of view. It was recently investigated by a Hom $\theta$ Office Departmental Committee, $\ddagger$ of which I was a member.

As is well known, ordinary coal-gas is made by heating coal in fire-clay retorts. The gas driven off from the coal is conducted by pipes to condensers and purifiers, where it is freed from tarry vapours, sulphuretted hydrogen, ammonia, carbonic acid, and other impurities, and then passed on to a gas-holder for storage. The purified gas is a complex and somewhat variable mixture, consisting of about 50 per cent. of hydrogen, 35 per cent. of marsh-gas $\left(\mathrm{CH}_{4}\right), 7$ per cent. of carbonic oxide (CO), 4 per cent. of ethylene $\left(\mathrm{C}_{2} \mathrm{H}_{4}\right)$ and other hydro-carbons, and a little nitrogen.

Carburetted water-gas is usually made as follows:-A towershaped furnace known as the "producer" is filled with coke. This is first blown up to a white heat with a blast of air. The air-blast is then turned off, and steam driven through the coke. The steam is decomposed according to the reaction $\mathrm{C}+\mathrm{H}_{2} \mathrm{O}=\mathrm{CO}+\mathrm{II}_{2}$, and the mixture of carbonic oxide and hydrogen which issues is ordinary "water-gas." - This has a non-luminous flame when burnt, and would therefore be useless for lighting purposes except with incandescent burners. The water-gas is therefore passed on tor a further chamber or pair of chambers (the "carburetter" and "superheater"), where it is "carburetted." The carburetter is a fire-

* Read before the Incorporated Society of Medical Officers of Health, February, 1900.

+ Sce p. 545 for a list of gas undertakings in this country supplying watergas.

\pm The Report of the Committee was published as a Mlue-book in 1899 . 
brick chamber, kept at a red heat by the gases from the producer, into which, while the water-gas is passing; petroleum oil is injected. The oil is "cracked," or converted into gas, by the heat, and the gas so formed mingles with the water-gas. The final mixture which issues from the carburetter and super-heater has a luminous flame when burnt, and is known as carburetted water-gas. The lighting and heating power of this gas varies with the proportion of oil used. It has very much the same smell as ordinary coal-gas, and consumers would not know the difference. The working of a carburetted water-gas plant is extremely simple in practice; but of course steam and air must be alternately blown through, as the coke would rapidly cool if the steam were continued too long. The gas is purified in the same way as coal-gas, but the process of purification is somewhat simpler. The purified gas contains about 35 per cent. of hydrogen, 80 per cent. of carbonic oxide, 20 per cent. of marsh-gas, 10 per cent. of ethylene, etc., and a little nitrogen.

In this country there does not appear to be much difference as regards cost between coal-gas and carburetted water-gas, the difference which exists depending largely upon local conditions. It appears, however, to be often advantageous to use the water-gas process as a supplement to coal-gas manufacture. The water-gas plant takes up little space, is relatively inexpensive, and can be set in action on any emergency, such as a bad fog; with great rapidity as compared with coal-gas plant. The number of men required is also much smaller, so that.with water-gas plant a strike could bo more easily met. In the United States the relative prices of gascoal, petroleum, and anthracite suitable for making water-gas would appear to have led to the general introduction of carburetted water-gas. In most of the large towns ordinary coal-gas has almost ceased to be made.

Both coal-gas and water-gas are, of course, poisunous even when - largely diluted with air, and according to the general opinion of toxicologists the poisonous constituent is in each case carbonic oxide. The Departmental Committee were, however, confronted with opinions expressed by various chemists that other constituents besides carbonic oxide cause or contribute to the poisonous effects of coal-gas. They therefore asked Dr. Lorrain Smith, of Queen's College, Belfast, to carry out a series of precise experiments on the subject with the coal-gas and carburetted. water-gas made in that town. These experiments, which are described in Appendix VII. of the Committee's Report, leave no room for doubt that the poisonous effects of both coal-gas and carburetted water-gas are due to the carbonic oxide alone. The other constituents are perfectly 
harmless in comparison, and contribute nothing to the poisonous effects.

As regards the mode of action of carbonic oxide, it has of course been well known since the publication of Claude Bernard's clnssical researches on the subject that this gas enters into combination with the hrmoglobin of the blood to the exclusion of oxygen. The most probable explanation of its poisonous action 'was, therefore, that it caused death by interfering with the oxygen supply to the tissues. This explanation was on various grounds doubted by some investigators, but four years ago I was able to prove its correctness by the following experiment:* An animal was placed in a strong glass ressel, into which pure oxygen was first driven to a pressure of two atmospheres. At this high pressure sufficient oxygen, as both previous calculation and the actual result of the experiment showed, goes into simple solution in the arterial blood to support life quite apart from the oxygen-carrying power of the hromoglobin. Carbonic oxide was then forced into the ressel to a pressure of a whole extra atmosphere, but the animal. was hardly affected, although on killing it inside the ressel its hrmoglobin was found by analy'sis to be completely saturated with carbonic oxide. The conclusion is evident that the poisonous action of carbonic oxide is due solely to its property of combining with hæmoglobin and thus interfering with the oxygen supply to the tissues. This sonclusion was further confirmed by the observation that carbonic oxide had no action at all on invertebrate animals which are not provided with liæmoglobin.

To measure accurately the extent to which blood is saturated with carbonic oxide I dovised the following method, which depends upon the fact that normal blood, when -sufticiently diluted with water, has a yellow colour, whereas blood saturated with carbonic oxide forms a pink solution when similarly diluted. A solution of ahout 1 of normal blood to 100 of water is made; also a solution of carmine dissolved with the help of a little ammonia, and diluted till its depth of tint is about the same as that of the blood solution. Tro test-tubes of equal diameter (about half an inch) are then selected. Into one of these 5 c.c. of the blood solution are measured with a pipette; into the other about an equal quantity is poured. Ordinary lighting gas is then allowed to blow into the second testtube through a piece of rubber tubing for a fer seconds. The testtube is then quickly closed with the thumb before the gas has time to escape, and the blood solution thoroughly shaken up with the gas for a few seconds. The hxmoglobin is thus completely saturated

* Journal of I'lysiology, rol xviii., p. 201 ; and vol. xxi., p. 161. 
with carbonic oxide, and the solution has now the characteristic pink tint. The carmine solution, which has a still pinker tint, is now added from a burette to the 5 c.c. of normal blood solution in the other test-tube until the tints are the same in the two testtubes. Not only, however, must the tints be equal in quality, but they must also be sensibly equal in $d e p t h$. If the carmine solution is too strong or too weak, the latter will not be the case, and the solution must be diluted or made stronger accordingly. It is usually easiest to make the carmine a little too strong at first, so that on adding both carmine solution and water equality can be established. From the amount of water which required to be added it is easy" to calculate the extent to which the original carmine solution needs to be diluted. The solutions are now ready for use, and the actunl analysis is made as follows : -5 c.c. of the solution of normal blood are measured into one of the test-tubes, and a drop of the suspected blood placed in the other test-tube and cautiously diluted with water till its depth of tint is about equal to that of the normal solution. If carbonic oxide be present in the hæmogilobin, a difference of quality in the tints of the two solutions will now be clearly perceptible. Carmine solution is then added from the burette to the normal blood, and water, if necessary, to the abnormal blood, till the tints are equal in both quality and depth. The carmine is added by about $0 \cdot 2$ c.c. at a time, the points being noted at which there is just too little and just too much carmine, and the mean being taken. The solution of abnormal blood is then saturated with coal-gas, and the addition of carmine to the other test-tube continued until equality is again established, and the amount of carmine noted. The percentage saturation with carbonic oxide of the abnormal blood can now be easily calculated, since we know how much carmine solution its saturation represented as compared with what complete saturation represented.

The method of calculation is illustrated by the following example: To 5 c.c. of normal blood solution, $2 \cdot 2$ c.c. of carmine is required to be added to produce the tint of the blood under examination, and $6 \cdot 2$ c.c. to produce the tint of the same blood fully saturated. In the former case the carmine was in the proportion of 2.2 in $7 \cdot 2$, and in the latter of $6 \cdot 2$ in 11.2 . The percentage saturation $(x)$ of the hremoglobin with carbonic oxide is thus given by the following proportion sum :

$$
\frac{6 \cdot 2}{11 \cdot 2}: \frac{2 \cdot 2}{7 \cdot 2}:: 100: x
$$

$x$ is therefore $=55.2$. As the compound of carbonic oxide and hrmoglobin is to a slight extent dissociated when the blood is 
diluted with water, the value found is a little too low. The corrections needed are as follows: Add 0.5 if 30 per cent. saturation be found, $1 \cdot 1$ if 50 per cent., $1 \cdot 6$ if 60 per cent., $2 \cdot 6$ if 70 per cent., 4.4 if 80 per cent., 10.0 if 90 per cent. Thus, in the above example, we must add $1 \cdot 3$, so that the true saturation is 56.5 per,cent. In comparing the tints the test-tubes should be held up against the light from a winclow, but bright light should be avoided as much as possible, as it increases the dissociation. Failing daylight, an incandescent burner with a chimney of blue glass and an opal globe may be used as the source of light.

When only a rough quantitative estimate of the. percentage saturation is required, as in ordinary post-mortem examinations or in examining the blood of a patient suffering from gas-poisoning, all that is necessary is to prepare in three test-tubes of even size (1) a solution of normal blood, well diluted; (2) some of the same solution saturated with coal-gas; and (3) a solution of the suspected blood diluted to the same depth of colour as the other two solutions. One can then tell roughly by the relative pinkness of the suspected blood to what extent it is saturated. No other known test for carbonic oxide in blood approaches in delicacy, accuracy, and simplicity that just described. The spectroscopic test, for example, is useless if the blood is less than about 50 per cent. saturated. The normal blood required may easily be obtained from a prick of the finger.

Distinct symptoms of CO poisoning do not begin to appear until the blood is about a third saturated.* The first noticeable symptom is a tendency to dizziness or fainting on exertion. At 50 per cent. saturation the smallest exertion may cause fainting, and mental porrer is much affected, though in different ways in difierent persons. Often enough, apparently, a man under the influence of CO behaves almost as if he were drunk. Beyond 50 per cent. saturation the symptoms become more and more alarming, and at death the saturation usually found is about 70 or 80 per cent. Sometimes, horrever, it is not more than 60 per cent., while occasionally it is as high as 85 per cent. $t$

As little as 0.2 per cent., or even less, of $\mathrm{CO}$ in air is sometimes fatal to animals, but usually 0.4 per cent. is required to cause death unless the exposure bo very prolonged, There is every reason to believe that the same holds good for men.

'To understand the phenomena of CO poisoning it is necessary to

* Journal of Physiology, vol. xviii., p. 430.

+ Haldane, "Report to the Home Secretary on the Causes of Death in Colliery Explosions and Fires, 1896 ": Lorrain Smith, British Medical Journal, 1899 , vol. i., p. 780 . 
bear in mind that although the compound of $\mathrm{CO}$ with hxmoglobin is relatively stable, yet oxygen in sufficient excess can to a greater or less extent prevent its formation, or drive out the $\mathrm{CO}$ already combined. Thus, hæmoglobin brought into intimate contact with air containing 0.07 per cent. of $\mathrm{CO}$ will finally reach a state of equilibrium in which it is saturated to an equal extent with $\mathrm{CO}$ and oxygen. If the percentage of $\mathrm{CO}$ or oxygen in the air be increased or diminished, there will be an exactly corresponding increase or diminution in the relative share of the hrmoglobin which either gas obtains. Air containing $2 \times 0.07=0.14$ per cent. of $\mathrm{CO}$ will, for instance, produce two-thirds saturation with $\mathrm{CO}$, and one-third saturation with oxygen, and so on. In the living body the proportion of $\mathrm{CO}$ taken by the hæmoglobin from respired air containing a given percentage of $\mathrm{CO}$ is not so large as outside the body, about 0.1 per cent. of $\mathrm{CO}$ in the air breathed being necessary to produce half-saturation of the hemoglobin.* The general law of absorption is, however, much the same, and it follows that there is a certain maximum of saturation for each percentage. With less than 0.05 per cent. of $\mathrm{CO}$ in the air this maximum does not exceed 33 per cent. saturation, and the corresponding symptoms are scarcely appreciable, except on muscular exertion. With more than about $0.2 \mathrm{per}$ cent. the maximum exceeds 60 per cent. saturation, and life then begins to be endangered. With normal breathing and about 0.1 per cent. of $\mathrm{CO}$ in the air the maximum is reached in about one and a half to two hours, but with more than 0.2 per cent. of $\mathrm{CO}$ the danger point will be below the point of maximum absorption, and the time required to reach it will become shorter and shorter in direct proportion to increase in the percentage of $\mathrm{CO}$ in the air.

In recovery from $\mathrm{CO}$ poisoning the $\mathrm{CO}$ is driven out from the hrmoglobin by the oxygen of the air, and escapes in the breath. It is not oxidized in the body. $\dagger$ An hour's breathing of fresh air will suffice in man to remove any dangerous excess of $\mathrm{CO}$ from the blood, and after three hours the blood is nearly free, although the damage done to the brain, heart, and other tissues during their partial deprivation of oxygen may cause persistent symptoms and often death. Recovery from even slight $\mathrm{CO}$ poisoning is usually accompanied by severe headache, lasting for many hours, and often associated with nausea or vomiting.

* A careful study of this phenomenon by Dr. Lorrain Smith and myself has led us to the conclusion that the oxygen tension of the blood leaving the lungs is higher than that of the alveolar air, and that the absorption of oxygen by the lungs is an active process, not due to mere diffusion. Cf. Journal of Pllysiology, vol. xxii., p. $231,1897$.

$\dagger$ Journal of Physiology vol. xxv., p. 225, 1000. 
The detection and determination of small percentages of $\mathrm{CO}$ in air was formerly a matter of great, and often almost insuperable, difficulty. I have recently, however, introduced a simple, and I think very satisfactory, method, depending on the already described action of $\mathrm{CO}$ on blood solution in presence of air.* The sample of air is collected in a clean and dry bottle of about 4 oz. capacity. The cork of the bottle is removed in the laboratory under a 0.5 per cent. solution of blood, and about 5 c.c. of the air allowed to bubble out, a corresponding volume of the blood solution entering. The cork is then replaced, covered with a cloth to keep off the light, and shaken continuously for about ten minutes, when the hiemoglobin will have reached the point of saturation corresponding to the percentage of $\mathrm{CO}$ present. The solution is then poured out into a test-tube, and the saturation determined with carmine solution in the manner described above. It is evident that as in each case the saturation found corresponds to a definite percentage of $\mathrm{CO}$ in the air, it is easy to calculate this percentage. If $p$ be the percentage required, and $s$ the percentage saturation found, $p$ is calculated from the following formula :

$$
p=\frac{s \times 0.07}{100-s}
$$

Thus, if $s=60, p$ is $0 \cdot 105$. This method may also be used for the direct determination of carbonic oxide in lighting-gas. The latter must, however, be first diluted to $\frac{1}{10 \sigma}$ (or with carburetted watergas to $\frac{1}{100}$ ) with air. As it is quite easy to make this dilution with perfect accuracy, the method is an exact one, and is not only rapid, but aroids the difficulties and sources of error connected with the ordinary method of determination by cuprous chloride, or by explosion. The apparntus which I. use for the purpose is on the table.

I now come to the question of the risls connected with carburetted water-gas. First of all, the risks connected with its manufacture may be dealt with. Of course, water-gas is more poisonous than coal-gas, and, other things being equal, the risks of poisoning to a workman would be greater. Such increased risk as might exist can, however, easily be avoided, particularly as the plant used requires very little unskilled labour, and is under the constant and immediate control of skilled engineers, so that dangerous escapes of gas are very improbable. So far as I have been able to judge, both from the evidence brought forward before the Departmental Committee and from independent personal inquiry,

* Journal of Physiology, vol. sxii., p. 478, 1808. 
the employment of the men engaged in the manufacture is, according to all ordinary standards, a safe and healthy one in actual practice.

As regards the risks to the public who use carburetted water-gas, the case is very different. By far the clearest evidence on this subject is obtained from the statistics of gas-poisoning in American towns, where undiluted carburetted water-gas is to a large extent used. A valuable summary of these statistics is given by $\mathrm{Dr}$. Parsons in Appendix No. II. of the Water-Gas Committee's Report; while further important data are contributed in Appendix No. VI. by $\mathrm{Mr}$. A. C. Humphreys, a very eminent American gas engineer. The clearest statistics are those of Boston, where, in accordance with an Act passed by the Legislature in 1888, the accidents from illuminating gas are annually reported by the Massachusetts Board of Gas and Electric Light Commissioners.

The following table, given in a letter by $\mathrm{MI}$. W. S. Allen, formerly Secretary to the Board, shows the effects of the introduction of water-gas, as shown by the Board's records since June, 1888:

\begin{tabular}{|c|c|c|c|c|c|c|}
\hline \multirow{3}{*}{ Year. } & \multirow{3}{*}{$\begin{array}{c}\text { Popula- } \\
\text { tion. }\end{array}$} & \multirow{3}{*}{ Cubic Feet of Gas sold. } & \multirow{3}{*}{$\begin{array}{c}\text { Percentage of } \\
\text { Cirburetted } \\
\text { Water-gas. }\end{array}$} & \multicolumn{3}{|c|}{ DEATHS From Gas INHaLation. } \\
\hline & & & & \multicolumn{2}{|c|}{ Reported as } & \multirow{2}{*}{ Total. } \\
\hline & & & & Accidental. & Suicldal. & \\
\hline 1888 & ... & $1,513,000,000$ & $1 \cdot 0$ & 0 & 0 & 0 \\
\hline 1689 & $\ldots$ & $1,643,000,000$ & $1 \cdot 5$ & 1 & 0 & 1 \\
\hline 1890 & 448,778 & $1,761,000,000$ & $8 \cdot 0$ & 4 & 2 & 6 \\
\hline 1891 & $\ldots$ & $1,859,000,000$ & $32 \cdot 0$ & 7 & 2 & 9 \\
\hline 1892 & $\ldots$ & $1,814,000,000$ & $52 \cdot 0$ & 5 & 8 & 13 \\
\hline 1893 & & $1,700,000,000$ & $67 \cdot 0$ & 17 & 6 & 23 . \\
\hline 1894 & $\ldots$ & $1,708,000,000$ & 88.0 & 16 & 10 & 26 \\
\hline 1895 & 496,920 & $1,875,000,000$ & $90 \cdot 0$ & .16 & 8 & 24 \\
\hline 189 & & $2,263,000,000$ & $89 \cdot 0$ & 31 & 17 & 48 \\
\hline 1897 & & $2,351,000,000$ & $93 \cdot 0$ & 32 & 15 & 47 \\
\hline
\end{tabular}

The table on the next page, which I drew up for the Water-Gas Committee from all the available data, further illustrates the effects of introducing carburetted water-gas.

These statistics bring out two points, one being that coal-gas is an extraordinarily safe illuminant, so far as risks of poisoning are concerned; the other, that the loss of life from poisoning is fully a hundred times as great with undiluted carburetted water-gas as with coal-gas. Of the deaths so caused only about half are accidental, the rest being chiefly suicidal, although a few are homicidal.

The risk of poisoning in the American towns supplied with carburetted water-gas is certainly very appreciable. Assuming that 


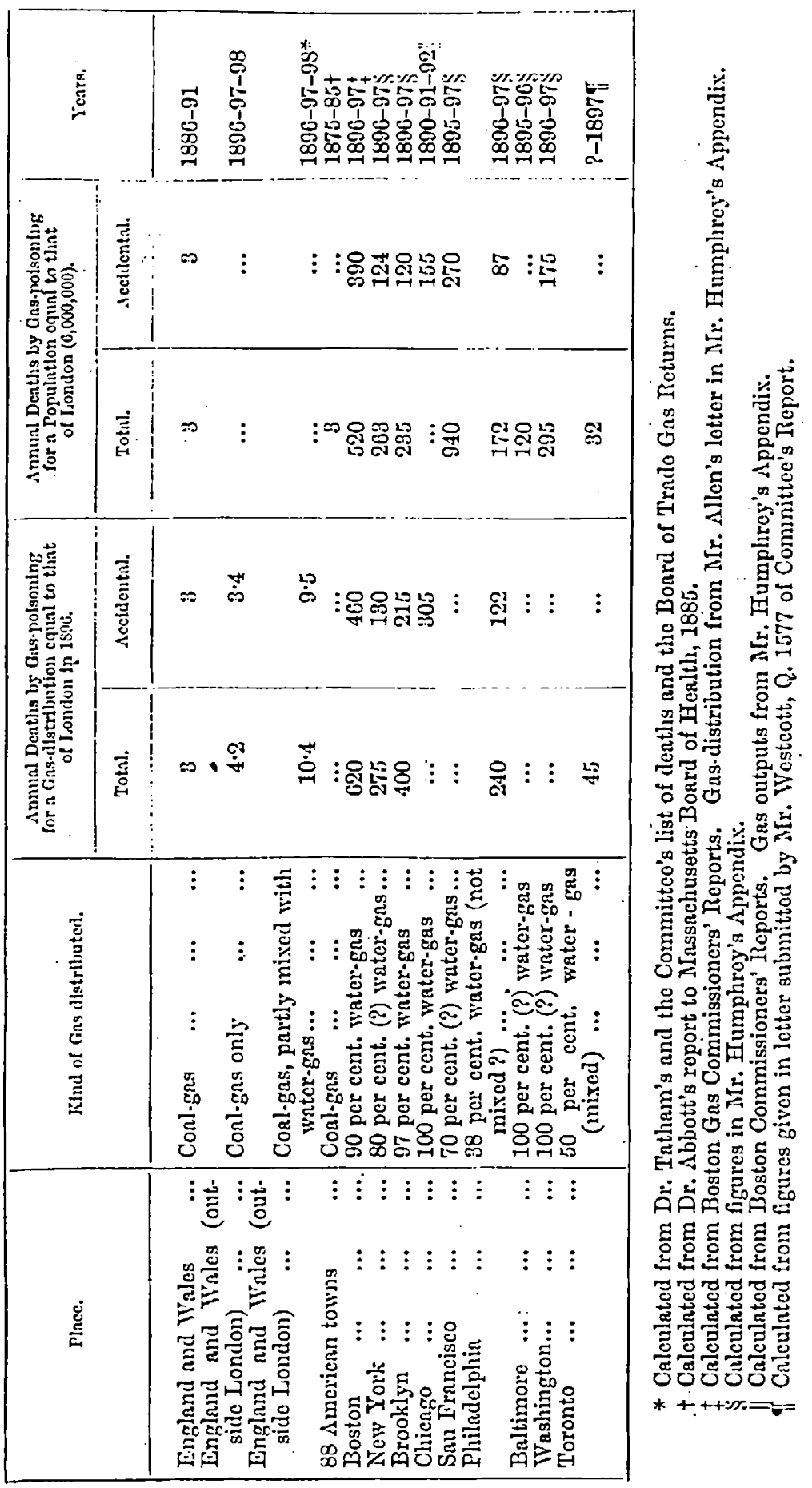


Boston has a death-rate equal to that of London, about one in every two hundred deaths is due to water-gas poisoning, or one in three hundred to accidental water-gas poisoning. This represents an annual death-rate about the same as that of "child-birth" or of "suicide," as returned in the official statistics of England and Wales for 1880 to 1890 . The total death-rate from poisoning of every hind in this country, whether by gases, liquids, or solids, and whether accidental or suicidal, is only about half the average deathrate from water-gas poisoning alone in Boston, New York, San Francisco, and Washington.

In order to show the manner in which the deaths from water-gas poisoning occur, I have drawn up the following table, which represents an analysis of the 281 fatal cases reported by the Massachusetts Board since 1889 :

\begin{tabular}{|c|c|c|}
\hline Source of Gas Escape. & $\begin{array}{l}\text { - Percentage } \\
\text { of Accidents. }\end{array}$ & $\begin{array}{l}\text { Percentage } \\
\text { of Suicides. }\end{array}$ \\
\hline 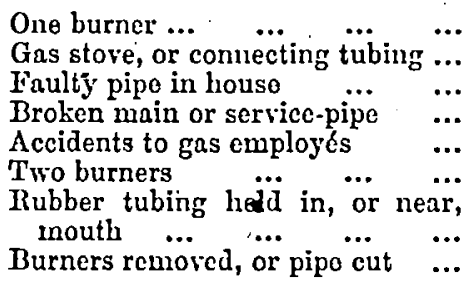 & $\begin{array}{r}81 \\
9 \\
3 \\
5 \\
2 \\
0 \\
0 \\
0\end{array}$ & $\begin{array}{r}55 \\
0 \\
0 \\
0 \\
0 \\
17 \\
\\
14 \\
14\end{array}$ \\
\hline Total & 100 & 100 \\
\hline
\end{tabular}

It will be seen that four-fiiths of the accidents and most of the suicides were due to escapes from single burners. The accidents arose almost invariably from frilure to turn off the gas on going to bed. It is probable that occrsionally the gas was blown out through ignorance, or was extinguished by some accidental cause when left burning; but there can be little doubt that in the great majority of cases the tap was accidentally turned on again after being turned off. The latter is by no means an uncommon occurrence, and in my own experience I can recall several cases in which it has occurred-fortunately not with carburetted water-gas.

When a gas-jet is accidentally left turned on in a room, it is evident that the effect on a person sleeping in the room will depend upon the percentage of $\mathrm{CO}$ which accumulates in the air at a level of about 3 feet from the floor. This will depend upon four factors: (1) the rate of escape; (2) the rate at which air is entering (or leaving) the room; (3) the degree of completeness with which the 
gas mixes with the air of the room; and (4) the percentage of CO in the gas. As regards the first three of these factors, our existing linowledge was very defective, and accordingly I undertook to investigate them in connection with the work of the Committee.

With respect to the first factor, the following table shows the rates of escape from a set of the most commonly used burners-Bray's "enamel regulator" - the tap being turned full on, and the pressure being 1.7 inches of water, which is about the ordinary nightpressure. On examining various taps I found that about the inaximum flow of gas from the burner was given through an angle of from 60 to 80 degrees out of the 180 degrees through which the taps turned between the two stops, so that, in the event of a tap being accidentally tumed on, the chances are very considerable that the maximum outflow will occur :

$\begin{array}{ccccccccc}\text { Number of Burner. } & 1 & 2 & 3 & 4 & 5 & 6 & i & \delta \\ \text { Escape in cubic feet per hour ... } & 5 \cdot 5 & 6 \cdot 1 & 7 \cdot 5 & 8 \cdot 2 & 9 \cdot 5 & 11 \cdot 0 & 11 \cdot 8 & 1.4 \cdot 8\end{array}$

It will be noted, for instance, that a No. 4 burner, which is meant to burn about 4 feet of gas per hour, will pass trice this quantity if the gas is unchecked, even at the low night-pressure.

As regards the rate of ventilation of ordinary closed rooms, I made a very large number of experiments in various binds and sizes of rooms. The methods employed were two. In the first series gas was allowed to escape from an ordinary jet at a known rate, measured by a meter, into the room, the conditions being such that the gas mixed thoroughly with the air of the room, as shown by the equality in the percentages found near the roof and near the floor. Samples of the air were taken at intervals, until a point was reached at which the percentage of gas ceased to increase. It was then of course easy to calculate by a simple proportion sum the rate at which air was entering or leaving the room. In the second series four candles- weighed at the beginning and end of the experiment-were placed on the floor, lighted, and allowed to burn until the percentage of $\mathrm{CO}_{2}$ in the air became constant. The amount of $\mathrm{CO}_{2}$ produced per gramme of candle burnt had been previously determined in an animsl respiration apparatus, so that the rate of ventilation could be calculated from the analyses as before. Nearly 200 analyses were made, the gas analysis apparatus used being that which I recently described in the Journal of Physiology, vol. xxii., p. 465,1898 , and which is extremely convenient for public health work, as the method is both rapid and accurate, and a sample collected in a $2 \mathrm{oz}$. medicine bottle is sufficient for a double analysis.

As might have been expected, I found that the rate of inflow of air varied with the amount of wind outside, the difference of 
temperature between outside and inside, and other conditions. l'hus, with a good breeze the rate of inflow was about doubled. An open fireplace, with no fire burning, about doubled the rate of inflow in a room of 1,400 cubic feet, while a fire burning increased the ventilation ten times. With a difference of temperature of $18^{\circ} \mathrm{F}$. between inside and outside, the ventilation was increased three times by opening the lower sash of the window 4 inches. With increasing size of room the rate of inflow-other things beingr equal-increased about in proportion to the increased surface of wall, floor, and roof, and not in proportion to the size of the room. 'l'his result is, I think, one of special interest, as showing that the value of "cubic space per person" in a large room with "natural ventilation" is quite different from that in a small room. For instance, in a small bedroom of 500 cubic feet capacity, with all openings closed, the natural ventilation through walls, etc., would amount to 280 cubic feet per hour, whereas in a large room of 30,000 cubic feet it would be only 70 cubic feet per hour for each 500 cubic feet of capacity. Thus, in large rooms or halls, which, when crowded; often only afford about 200 cubic feet per person, special means of ventilation become almost a necessity. It is in large, and not in small, rooms that one finds air which contains a largo excess of $\mathrm{CO}_{2}$. In the worst class of one-roomed dwellings, with an average of 1,400 cubic feet per room and 212 cubic feet per person, Carnelley and I found an average of only $6 \cdot 6$ volumes per 10,000 in excess of outside air, although the samples were all taken in the middle of the night. In churches and other badlyventilated buildings one commonly finds from five to ten times this excess.

The following table, calculated from the results of the experiments, shows the time required for a volume of air equal to that of the room to onter, door, window, and fireplace, if any, being closed, and there being no wind and not more than a few degrees of difference of temperature between inside, and outside-in other words, the conditions for natural ventilation being most unfavourable:

\begin{tabular}{|c|c|}
\hline $\begin{array}{c}\text { Cubie Cupacity of Room } \\
\text { in Cuble Feet. }\end{array}$ & $\begin{array}{c}\text { Timo in Hours requircd for } \\
\text { volume of dir equal to that of } \\
\text { the Hcom to enter. }\end{array}$ \\
\hline 500 & $1 \cdot 8$ \\
750 & $2 \cdot 1$ \\
1,000 & $2 \cdot 3$ \\
1,500 & $2 \cdot 65$ \\
2,000 & $2 \cdot 9$ \\
3,000 & $3 \cdot 3$ \\
4,000 & $3 \cdot 6$ \\
\hline
\end{tabular}


A house with stone walls gave very much the same result as a house with much thinner brick walls, so that it seems probable that as regards the facility with which air permeates inwards and outwards there are, as a rule, not very great differences between the rooms in different houses. Of course, however, there must be exceptional cases. In the cabin of a ship, for instance, the walls, roof, and floor must bo almost air-tight, except in so far as ventilation is specially provided for.

I now come to the third factor-the degree of completeness with which gas escaping from a jet mixes with the air of a room. It is evident that the escaping gas must at first ascend, since its specific gravity is only about half that of air. What afterwards becomes of it $?$ It might simply pass bodily out through the porous ceiling without previous mixture; it might be brought rapidly down from the roof and thus thoroughly mixed with the air of the room by convection currents; or it might mix slowly with the air below by simple diffusion downwards ; or, finally, it might do more than one of these things at the same time. For the person sleeping in the room, what actually occurred might be a matter of life and deatl. The experiments showed that the behaviour of the gas depended entirely on certain definite circumstances, and that in the case of an actual escape sometimes one result and sometimes another followed.

When there was only a very slight difierence of temperature between inside and outside, as was usually the case by day, except in winter, the gas escaping from a jet was found to remain almost entirely near the roof, and not to come down to any considerable extent. After a time the escape of gas through the ceiling, etc., became equal to the escape from the burner, so that no further gas accumulated. As an example of this lind of result I may talio experiment No. 7 (Appendix No. 1 of Report), in which, after an escape of four hours' duration from a No. 7 burner in a room of 1,100 cubic feet caprcity, I found $2 \cdot 82$ per cent. of gas near the roof, and only 0.20 per cent. at 3 feet from the floor. The analysis brought out a further interesting point, namely, that the gas present near the floor consisted almost entirely of hydrogen, while the gas near the roof was less rich in hydrogen than the original gas. Evidently the constituents of the original gas had to a large extent separated by diffusion in the room, and as the hydrogen is by far the most diffusible constituent, it had diffused downwards most rapidly.

At night, on the other hand, when the outside temperature was considerably lower than that inside, the usual result was that the 
gas soon became mixed equally throughout all parts of the room. Investigation showed that this was due to convection currents down the cold windows. The gas in the room was also on the whole less rich in hydrogen than the original gas, as some of the hydrogen had diffused out through the walls, etc. The circumstance that at night the gas usually comes down from the roof and mixes with the air below is evidently an unfortunate one so far as the chances of eacape for a person sleeping in the room are concerned.

Another peculiar fact discovered with regard to gas-escapes was that when the escape was a very large one there was much less tendency for the gas to come down from the roof, even at night. Thus in one experiment, after an escape of 50 cubic feet per hour for two hours from a bracket from which the burner had been unscrewed, there was only 0.86 per cent. of gas at 3 feet from the floor, although there was 8.23 per cent. at the roof. Even on a cold night, after a similar escape of five hours' duration, there was only 2.36 per cent. at 3 feet with 8.32 per cent. near the roof. When there is a large accidental escape of gas in a room, as from pulling down too far a sliding chandelier from which the water has partially evaporated, it is often the person sleeping in the room above who is poisoned, and the results first referred to make it easy to understand this fact. I may add that I never succeeded in producing an explosive atmosphere in any part of a room by an escape from a burner, although when the burner was taken off the air near the roof soon became explosive.

I may now proceed to the consideration of the fourth factor, namely, the percentage of carbonic oxide in the gas. The following table, which is calculated from the data already given sbove,

\begin{tabular}{|c|c|c|c|c|c|c|c|c|}
\hline \multirow{2}{*}{$\begin{array}{l}\text { Size of Room } \\
\text { in Cubic Fect. }\end{array}$} & \multirow{2}{*}{$\begin{array}{l}\text { Outfiow of } \\
\text { Gis in } \\
\text { Cubic Fect. }\end{array}$} & \multirow{2}{*}{$\begin{array}{c}\text { Sizc } \\
\text { of Bray's } \\
\text { Burner. }\end{array}$} & \multicolumn{6}{|c|}{$\begin{array}{l}\text { Final Percentage of CO in Air with cocaping } \\
\text { Gas containing }\end{array}$} \\
\hline & & & $\begin{array}{l}5 \mathrm{rer} \\
\text { cent. }\end{array}$ & $\begin{array}{l}10 \text { per } \\
\text { cent. }\end{array}$ & $\begin{array}{l}15 \text { per } \\
\text { cent. }\end{array}$ & $\begin{array}{l}90 \text { per } \\
\text { cent. }\end{array}$ & $\begin{array}{l}25 \text { per } \\
\text { cent. }\end{array}$ & $\begin{array}{l}30 \text { por } \\
\text { cent. }\end{array}$ \\
\hline 500 & $9 \cdot 1$ & 4 & 0.16 & 0.33 & 0.49 & 0.66 & 0.82 & 0.98 \\
\hline 750 & $9 \cdot 1$ & 4 & 0.13 & 0.25 & $0.3 \delta$ & 0.51 & 0.76 & 0.89 \\
\hline 1,000 & $10 \cdot 6$ & 5 & 0.12 & 0.21 & $0 \cdot 36$ & 0.48 & 0.60 & 0.72 \\
\hline 1,500 & $12 \cdot 3$ & 6 & 0.11 & 0.22 & 0.33 & 0.44 & 0.55 & 0.66 \\
\hline 2,000 & $13 \cdot 2$ & 7 & 0.09 & 0.19 & 0.28 & 0.38 & 0.47 & 0.56 \\
\hline 3,000 & $13 \cdot 2$ & 7 & 0.07 & 0.14 & 0.21 & 0.28 & 0.35 & 0.42 \\
\hline 4,000 & $18 \cdot 2$ & 7 & 0.06 & 0.12 & 0.18 & 0.21 & 0.30 & 0.36 \\
\hline
\end{tabular}


shows the maximum percentages of $\mathrm{CO}$ which are likely to accumulate in rooms of different sizes with continuous escapes of gas occurring under the most unfavourable conditions as regards ventilation, etc., with varying proportions of $\mathrm{CO}$ in the gas. The percentages in italics (from -2 to ${ }^{-4}$ per cent.) would be dangerous, and those in thick type (above 4 per cent.) would probably prove fatal. The escapes would, of course, need to continue for two or three hours before the percentages specified were actually reached.

A glance at this tablo will explain at once the greatly increased risk of poisoning when carburetted water-gas is used, and the, at first sight, anomalous fact that although there is only about four times as much carbonic oxide in carburetted water-gas as in coalgas, yet the increase in the number of deaths from poisoning is enormously greater than four times when the former lind of gas is used. On examining the statistics of towns using pure coal-gas, pure carburetted water-gas, and mixtures of the two, I calculated that, roughly speaking, the risk of accidental poisoning increases with the cube of the relative increase in the percentage of $\mathrm{CO}$.

I must now refer shortly to poisoning cases which occur through escapes of gas into houses from broken mains or service pipes. These breaks seem usually to occur after some disturbance of the ground caused by digging up the street, and sometimes from the passage of steam-rollers. Very large volumes of gas may thus escape into houses, with most serious effects to the inhabitants. Since the researches of Pettenliofer on this subject, it has also been well-known that the gas may, to $\bar{a}$ greater or less extent, be deodorized in passing through the ground, with the result that the true cause of the illness or death caused by the escape is not recognised. When carburetted water-gas is used, escapes from mains are specially serious, and large numbers of persons may bo affected. Thus, to talie one instance recorded in Boston in 1887, about a hundred persons, occupying the blocks of houses on either side of a street in Boston, were more or less overcome by an escape of gas from a broken main. By good fortune the escape was discovered by a man who came home at about 2 a.m., and the people in the houses were soon rescued, only one being already dead.

As regards the use of carburetted water-gas in this country, in only one case has it been distributed unmixed for any length of time. This case was the notorious one of the Garston District on the outshirts of Liverpool, where the Liverpool Gas Company dis: tributed it.without warning of any lind for about a year, with the result that the proportion of fatal and non-fattal poisoning cases in the district was about the same as in Boston. A most effective 
protest by Surgeon-Lieutenant-Colonel Cayzer* brought the dangers of water-gas prominently before the public, and quickly led to a discontinuance of the supply at Garston. In many other towns, including London, a certain proportion of carburetted water-gasusually less than a fourth-is distributed along with the coal-gas. $f$ As regards the relative number of poisoning cases in towns where carburetted water-gas is used mixed with coal-gas, I came to the conclusion, after examining the records for the last three years, that, as shown in the table of statistics, there is a most distinct increase. Nevertheless the total number of cases is very small. In one or two towns or districts, notably Belfast and Tottenbam, the proportion distributed has been considerable. In Tottenham a 50 per cent. mixture has been distributed for several years, and no fatal accidents have been reported. In Belfast, however, where the proportion is variable, rumning up to 60 per cent., or, according to another statement, to 70 per cent., at times, the number of both fatal and non-fatal accidents has been considerable. During the last two years there have been eight or nine fatal accidents, which, considering the population of Belfast, is far above the ordinary proportion with coal-gas. The Belfast Coroner has again and again drawn attention to the subject during the last fow months in connection witle inquests.

There is at present nothing in the Acts of Parliament relating to gas distribution to prevent the distribution, without warning of any kind to the public, of either carburetted water-gas or any other mixture of gases suitable for lighting purposes. Of course, however, it would be contrary to the interests of either a gas company or a corporation to distribute any lind of gas which would cause complaint ; and in this country, at least, this is, perhaps, a pretty effective safeguard against the distribution of a dangerous kind. Nevertheless we are confronted with the case of the United States, where some hundreds of lives are annually sacrificed by water-gas poisoning, in spite of every protest. To give an idea of the anxiety sometimes caused in Americnn households by the use of water-gas, I may mention that the wife of a professor in one of the American Universities recently told me that she every night woke up and went to the nursery simply to see that the gas was not escaping. She said that the nowspapers seemed always to be full of gaspoisoning cases.

* See letters in the Public Heallh Engineer, 1897 to 1899. Colonel Cayzer informs me that in each of the two fatal cases at Garston there was an open fire. place in the bedroom. One of the rooms had a capacity of 1,050 , and the other of 612 cubic feet.

+ See p. 545 of this issue. 
The Water-gas Committee came to the conclusion that legislation with regard to water-gas is desirable; and their chief recommendation was " that power should be conferred upon a Central Department to make regulations, enforceable by adequate penalties, limiting the proportion of carbonic oxide in the public gas-supply at night to 12 per cent., or such greater amount as the Department may consider desirable." A 12 per cent. limit, valid only during sleeping hours-say from 10 p.m. to 7 a.m. -would allow of the distribution of a-very considerable amount of water-gas; and even by night about 20 per cent. could be distributed.

It may be asked, Why not abolish by law the use of carburetted water-gas altogether? Even in such a small proportion as 20 per cent., it is certainly less safe than coal-gas, and no consideration of expense should weigh against risks to life. It seems to me that an argument of this sort is unsound, and, as a matter of fact, is never followed out in practice. We are constantly exposing ourselves knowingly to small risks, and we must do so unless we make it our object simply to " survive" in the abstract, and not to live our own-lives. We are all agreed in thoroughly despising the persons who are constantly thinking of nothing but their own health and safety from danger or disease. Among other things we want light and heat. We get it to a large extent from gas, and we can only get as much as we can pay for: If we need mure, and can get it with our available means by taking additional risk, we take the risk unless it is an appreciable one, and we should very much object to being. interfered with in doing so by a grandmotherly legislation. The question as regards carburetted watergas is therefore one of balancing risk to life against other advantages; and for my own part I think that the Committee came to about the right conclusion in striking the balance at a 12 per cent. limit of carbonic oxide. Further, I think they were right to recommend that the limit should be an elastic one, to be rolaxed if it seemed desirable, at the discretion of a competent central authority. It is quite possible to overcome the difficulties connected with a safe distribution of carburetted water-gas. Moreover, it is quite conceivable that the relative advantage of carburetted water-gas may become greater in the future than it is at present:" For both of these reasons any cast-iron legislation on the subject seems distinctly undesirable.

At the close of his paper Dr. Haldane demonstrated on a sample of blood taken from the body of a man who had died of carbonic oxide poisoning (1) the method of roughly estimating by inspection 
of the diluted blood the degree to which the hamoglobin was saturated with carbonic oxide; and (2) the method of accurately determining the saturation with carmine solution. He also showed an apparatus for the purpose of determining by the blood-method the percentage of carbonic oxide in coal-gas. The apparatus consisted of (1) a sample-tube, provided with a tap at each end, and holding exactly 4 c.c. of gas; (2) a flask holding 400 c.c. of air. 'The gas from the sample-tube was forced into the flask of air by the pressure of a $:$ per cent solution of blood contained in a burette, about 5 c.c. of the blood solution being also forced in. The flask was then closed, disconnected, and shaken for at least five minutes, after which the blood solution was poured out into a test-tube and its saturation with carbonic oxide determined. From the saturation $(s)$ the percentage (p) of carbonic oxide in the air of the flask was calculated according to the formula $p=\frac{s \times \cdot 07}{100-s}$. As the gas in the flask was diluted to $\frac{1}{100}$ th with air, the percentage of carbonic oxide in the original gas was $p \times 100$.

\section{DISCUSSION.}

The Presidext said the Society was very much indebted to Dr. Haldane for bringing before them this subject, which had been somewhat neglected by medical ofticers of health, unany of whom probably knew very little about it until the issue of the report of the recent Departmental Committee. The risk was not at present one of great magnitude, but, as the Committee pointed out, it was very important that it should be regulated by legislation before it became unmanageable. In Anerica, for instance, it had possibly become almost too great to be attacked, and it would probably. now be impossible to alter the existing state of affairs. -The proportion of carburetted water-gas regarded by the Committee as a permissible maximum was very reasonable; but the gas companics would probably not be prepared to alter their present dangerous admixture of water-gas with conl-gas until compelled to do so by legislation. If the danger increascd with the proportion of water-giss, it was most important that they should urge Parliament to insist on its reduction to the proportion sugrested by the Departmental Committce. Dr. Haldane's paper would bring the matter before medical oflicers of health throughout the whole country. The simple method of analysis demonstrated to them for the first time that evening would enable cach of them to clieck the amount of water-gas supplied in domestic coal-gas. Dr. Inaldane's remarks on ventilation were of extreme interest. The relationship between air capacity and ventilation was one of the most inportant they had had before them for some time.

Mr. Pakes desired to cmphasize the importance of the relationship of rentilation to diffusion. - The largest room the air of which he had had the privilege of examining was the Albert Hall, in the middle and at the end of a concert. The amount of carbonic acid found present was 1.8 per 1,000, which bore out Dr. Haldane's statcments as to the great difficulty of getting such a place ventilated. Mr. Pakes referred to the panic at Hoscow, when the leath of a number of children occurred in a crowd in the open air, and he asked Dr. 
Iraldane whether, in his opinion, it was possible for suffocation to talic place in the open air. He thought the method of analyzing demonstrated that evening was easy and accuratc.

Mr. Brodderery (Tottenham Gas Company) said he was responsible for the distribution of $1,262,000,000$ cubic fect of carburetted watcr-gas mixed with $1,311,000,000$ eubic feet of coal-gas, a proportion of about 50 per cent.; but although they started with a lower proportion of carburctted water.gns, they were often now above 50 per cent. They would therefore look upon him as a cold-blooded poisoner. If he had any suspicion that this gas would spread death, he should hesitate to send it out at all. Dr. Haldane had told them that in Boston, U.S.A., 1 in every 300 deaths was due to gas-poisoning. In Tottenham, with a population of 220,000 , they had not had one single case where denth had been due to this poison, nor had they any illness or trouble of any description resulting from its use since its first distribution, five years and a quarter ago. They had 16,200 supplics, representing about 80,000 to 100,000 consumers of the gas. They attended to about 1,800 complaints of escapes during a yenr, and no doubt the local gasfitters attended to a great many more. With the enorinous number of escapes and of people using the gas, it seemed almost ineredible that its use should have been unattended with accident if they accepted what Dr. Haldane had sidd in his tables and argh. ments. Of course accidents would happen, and sometimes, perhaps, even from medicine; still, medicine had its proper purposes, and should be used for those purposes. So with gas, it was meant for burning and not for respiration. The supply of carburetted water-gas did not introduce carbonic oxide into a room where it was used. In the manufacture of carburetted water-gas there was far less risk than in the manufacture of coal-gas. He invited any member of the Society to visit heir works, and lie was sure they would say, in the interests of the workmen, that carburetted water-gas should be used. It wis well known that Scotch gas contained twice as much water-gas ns English, and he challenged Dr. Haldane to show an increased death-rate due to gaspoisoning in Scotland.

Mr. S. F. MUnpur, in moring that the thanks of the Society be accorded to Dr. Haldane for his paper, said the literature on this subject was scattered through many books and papers, and information could only be collated with great difticulty. Dr. Haldane had given them just this information in his valuable paper. He had put the matter very fairly and clearly before medical officers of health, and no class of ofticers was more likely to get morc useful results from the information supplied than those responsible for advising local authorities. He would not suggest that water-gas should not be used at all, but that it should be used only under limitation. He understood the Local Govern. iwent Board refused to sanction loans to gas companies because the Board could not enforce this limitation, and they therefore preferred that the companies should obtain their powers direct from Parliament.

Dr. Alsus seconded the rote of thanks to Dr. Haldane for his paper, which was one of a very ligh standard, and would give a considerable amount of information to medical officers of health. He believed many medical men had no idea that water-gas was being used to such an extent. Dr. Haldane said, if they wanted to enjoy certain comforts they must run certain risks, but even $\mathrm{MI}$. Broadberry would admit that if they were prepared to run those rishs, they were at least entitled to know what the risks were. The majority of people were unaware that they were using something more than conl-gas in their houses, and 
should be apprised of the fact that a very poisonous gas was being freely added to it. It was not fair to compare Tottenham with Boston (U.S.A.). In Totten. ham only about a third of the population had gas in their houses, and in many: instances it was not laid on all over the house; few probably used gas in the beclrooms by night, and no doubt a considerable number of the cubic feet of calburetted water-gas Mrr. Broadberry had referred to would be used in tho public streets. Mr. Broadberry said that no deaths had oceurred from its use, but Dr. Haldane had shown that small escapes were not fatal. Small escapes of coal-gas produced ccrtain effects on people breathing it for a long time, and breathing water-gas for a long period would have, some effect on health, although it night not be such as to come under the notice of the coroner. Mr. Broadberry referred to the Scotch gas; perhaps he would explain why they hrve given up the use of water-gas in Glisgow?

Dr. Handane in his reply, thanked the Society very heartily for their hind reception of his paper. As regards the question referred to by Mr. Pakes, ho thought it was hardly possible that the deaths in the crowd at Moscow could have been due to vitiation of the air, and that probably the actual cause of death was mechanical hindrance to the respiratory movements. With regard to Mr. Broadberry's remarks, he would point out that the total quantity of gas sent out by the Tottenham Company during the period referred to was only about onc-fiftecnth of that sent out by the three London companies in a single rear. According to the statisties given in the paper, only three necidental deaths would occur on an arcrage with this distribution of a 50 per cent. mixture of carburetted water-gas and coal-gas. The fnet that no deaths had actually occurred was therefore not surprising. In Belfast, however, where there was also a high proportion of carburctted water-gas, the distribution being on a larger scale, there lad been for a time a similar immunity from gas-poisoning, yet the pro. portion of deaths was now above the averagc. There had been four accidental deaths from this cause within a single week last January. He had no statistics of the actual number of cases of gas-poisoning in Scotland, but judging from newspaper reports, he thought the proportion was a good deal bighor than in England. He would point out, however, that in some Scotch towns, such as Filinburgh, the gras was of very liigh illuminating power, and had to be burnt from small-sized burners to prevent the thames from smoking. This would diminish the risk of accidental poisoning in these towns.

The voto of thanks, on being put to the meeting, was carried unanimously.

1): LArdien (Ticvuc d'Hygiène, 1894, 431) instances a case in which a cow dead of anthrax was eaten by a large number of people without the slightest ill-effects. Not so fortunate, however, were those who handled the carcass, which was the cause of a series of fatalities. Two men who helped skin the animal had typical charbon, but recovered. $A$ calf belonging to one of them was seized with the disease and died, and in the removal of its hide another man was pricked, and, in consequence, died. The head of the cow was sold to a woman who wounded herself in cutting it up, and died. The skin of the cow was sold to $a$ man who stored it in a shed on his farm, and a fow days later, one of his cows dying of the disease, a post-mortem examination was made, and in the process the operator wounded himself, and died. In addition, from seven to ten cats that ate of the refuse and blood of the original cow all died suddenly shortly afterward:-American Joumal. of . Nedical Science. 